\title{
Analisa Delaminasi Pada Glass Fiber Reinforced Polymer Komposit Laminat Dengan Pembebanan Fatigue
}

\author{
I Made Astika* \\ *Dosen Jurusan Teknik Mesin Fakultas Teknik Unud, Kampus Bukit Jimbaran \\ E-mail: made.astika@me.unud.ac.id
}

\begin{abstract}
Abstrak
Delaminasi merupakan salah satu dari model kerusakan kritis yang terjadi pada komposit laminat. Delaminasi terjadi karena beberapa faktor seperti tegangan interlaminar yang tinggi dan konsentrasi tegangan pada lokasi retak atau kerusakan lain pada laminat. Jika suatu laminat diberi beban fatigue, delaminasi dapat tumbuh dengan kenaikan jumlah cycle dan bisa menyebabkan kerusakan total pada laminat. Jadi ada keterkaitan antara karakteristik pertumbuhan delaminasi komposit laminat dengan kondisi pembebanan fatigue. Pada penelitian ini diamati pertumbuhan delaminasi pada komposit laminat yang didasarkan pada perhitungan kemungkinan pertumbuhan delaminasi pada semua tingkat pembebanan selama siklus pembebanan fatigue.

Penelitian ini adalah pengujian fatigue dengan pembebanan reverse bending dengan type specimen double cantilever beam (DCB). Pembuatan spesimen uji dilakukan dengan proses hand lay up dengan menggunakan dua lembar lamina berserat anyam (WR). Diantara kedua lamina disisipi dengan lembaran aluminium dengan ukuran $25 \times 75$ mm sebagai inisiasi retak. Ukuran specimen adalah $25 \times 230 \mathrm{~mm}$.

Hasil penelitian menunjukkan bahwa laju perambatan retak mengalami penurunan pada jumlah siklus yang meningkat. Bertambahnya siklus mengakibatkan faktor intensitas tegangan $\left(K_{I}\right)$ dan energi yang dibebaskan $\left(G_{I}\right)$ mengalami penurunan. Berkurangnya energi yang dibebaskan dan faktor intensitas tegangan berpengaruh pada distribusi tegangan pada ujung retakan mengakibatkan laju pertambahan retak menurun.
\end{abstract}

Kata kunci: komposit laminate, delaminasi, fatigue, retak

\section{Pendahuluan}

Dalam industri manufaktur sering kali memerlukan material yang mempunyai sifatsifat istimewa yang sulit didapatkan dari matrial konvensional. Komposit merupakan jenis material alternatif yang dapat digunakan untuk memenuhi kebutuhan tersebut. Keunggulan material komposit dibandingkan dengan material klasik adalah perbandingan kekuatan terhadap berat yang tinggi, perbandingan berat terhadap volume rendah (berat jenis rendah), kekakuan, ketahanan korosi, ketahanan aus dan arah kekuatan dapat dikendalikan. Kelemahan dari material komposit adalah proses pemesinan sulit dan tidak dapat didaur ulang, sehingga untuk mendapat hasil yang baik dilakukan dengan proses pencetakan yang memerlukan biaya dan teknologi tinggi.

Suatu komponen atau unit mesin pada pengoperasiannya akan menerima pembebanan statik atau dinamik. Pada pembebanan statik, suatu komponen akan aman jika mendapat pembebanan dibawah tegangan yieldnya dimana deformasi plastis tidak terjadi. Sedangkan pada pembebanan dinamik, suatu komponen dapat mengalami kegagalan pada pembebanan jauh dibawah tegangan yielnya.
Delaminasi merupakan salah satu dari model kerusakan kritis yang terjadi pada komposit laminat. Delaminasi terjadi karena beberapa faktor seperti tegangan interlaminar yang tinggi pada sudut-sudutnya dan konsentrasi tegangan pada lokasi retak atau kerusakan lain pada laminat. Beban impak yang rendah juga dapat menyebabkan terjadinya delaminasi di dalam laminate yang tidak dapat diamati dari luar. Jika suatu laminat diberi beban fatigue, delaminasi dapat tumbuh dengan kenaikan jumlah cycle dan bisa menyebabkan kerusakan total pada laminat. Jadi ada keterkaitan antara karakteristik pertumbuhan delaminasi komposit laminat dengan kondisi pembebanan fatigue. Pada penelitian ini diamati pertumbuhan delaminasi pada komposit laminat yang didasarkan pada perhitungan kemungkinan pertumbuhan delaminasi pada semua tingkat pembebanan selama siklus pembebanan fatigue.

\section{Dasar Teori}

2.1 Pembebanan Dinamik

Kegagalan dari suatu material yang mendapat pembebanan ditandai dengan luluh yang dominan atau patah yang dominan. Pada kegagalan luluh yang dominan cacat-cacat yang berarti adalah cacat yang cenderung untuk 
membengkokkan dan memutuskan bidang kisi kristal, kemudian bercampur dengan dislokasi dan memberikan tahanan terhadap deformasi.

Kegagalan patah yang dominan adalah patah sebelum terjadi luluh, skala ukuran cacat mempunyai arti yang cukup besar, dimana plastisitas tidak termasuk, hanya medan regangan-regangan lokal yang berkaitan dengan cacat tersebut.

Patah yang terjadi pada suatu komponen akibat beban yang berulang-ulang (dinamik) disebut patah lelah (fatigue).

\subsection{Kegagalan Pada Komposit}

Suatu struktur dikatakan gagal bila struktur tersebut tidak lagi berfungsi dengan baik. Sehingga definisi kegagalan dapat berbeda menurut kebutuhan yang berbeda. Untuk penerapan struktur tertentu deformasi yang kecil mungkin sudah dianggap gagal, sedangkan pada struktur lain hanya kerusakan total dianggap gagal. Hal ini sangat jelas terlihat pada komposit. Kerusakan internal mikroskopis dapat terjadi jauh sebelum kerusakan nyata dapat dilihat. Kerusakan internal mikroskopis ini dapat terjadi dalam beberapa bentuk seperti: patah serat, retak mikro pada matrik, lepasnya serat dari matrik dan terpisahnya lamina satu dengan yang lain. Untuk menganalisis kekuatan dari laminate dapat dipakai kriteria kekuatan pada lamina. Dari gambar dibawah dapat dilihat bahwa beban yang menyebabkan lamina pertama rusak bukan merupakan beban maksimum yang menyebabkan laminate patah. Karena laminate sendiri merupakan gabungan dari beberapa lamina yang mempunyai regangan maksimum yang berbeda-beda. Dalam analisis yang menyebabkan lamina pertama rusak dan lamina berikutnya maka stiffness matrik pada laminate harus berubah untuk menerangkan efek-efek dari patah tersebut.

\subsection{Analisa Perpatahan}

Pada analisa ini pendekatan yang dipakai adalah Strain energy Release $\left(\mathrm{G}_{\mathrm{I}}\right)$ karena pendekatan ini mudah dipahami dan

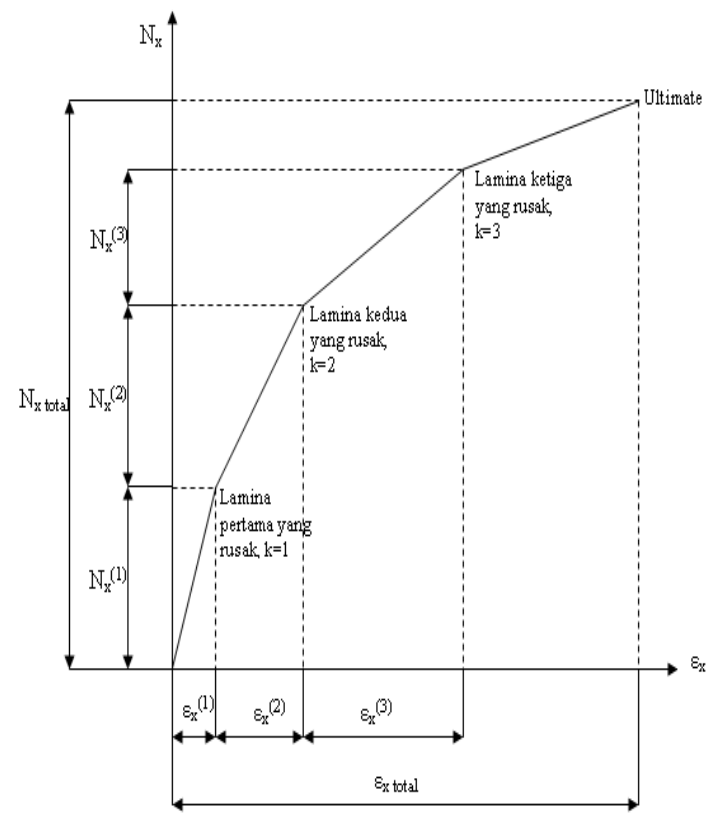

Gambar 2.1 Kurva beban-regangan menunjukkan lamina-lamina yang patah sebelum laminate

sama akuratnya untuk analisa material isotropic atau anisotropic dan juga menghubungkannya dengan Stress Intensity Factor. Konsep fracture mechanic ini sangat tepat digunakan untuk menganalisa pengaruh retak dan notch pada laminat komposit (Gibson 1994).

Perhitungan $\mathrm{G}_{\mathrm{I}}$ untuk percobaan DCB menggunakan metode Whithney et. Al (1982) dimana yang dianalisa adalah setengah dari specimen DCB. Dengan menggunakan teori mekanika material defleksi pada DCB adalah:

$$
\frac{\delta}{2}=\frac{P \cdot a^{3}}{3 \cdot E \cdot I}
$$

Dengan: $\quad \mathrm{P}=$ beban yang diaplikasikan

$\mathrm{a}=$ panjang batang uji

$\mathrm{E}=$ Modulus elastisitas $\mathrm{I}=$ Mome Inersia

Untuk menganalisa laju perambatan retak dari satu titik ke titik selanjutnya digunakan metode secant sebagai berikut:

$$
\frac{d a}{d N}=\frac{\left(a_{i+1}-a_{i}\right)}{\left(N_{i+1}-N_{i}\right)}
$$

Karakteristik perambatan retak yang merupakan hasil dari pengujian fatigue melalui eksperimen maupun melalui perhitungan analitis dapat ditampilkan dalam bentuk grafik, laju perambatan retak da/dN dengan faktor intensitas tegangan $\Delta \mathrm{K}$. 


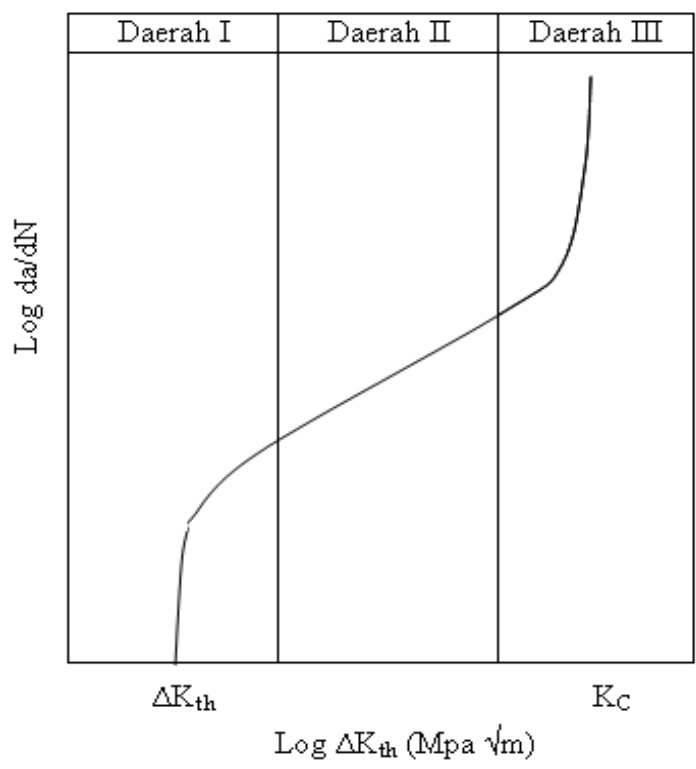

Gambar 2.2 Karakteristik umum perambatan retak akibat pembebanan fatigue

Berdasarkan gambar diatas, karakteristik umum perambatan retak dapat dibagi menjadi tiga daerah yaitu:

a). Daerah I

Daerah ini merupakan ambang batas perambatan retak. Mekanisme perambatan retaknya tidak kontinu. $\Delta \mathrm{K}_{\text {th }}$ merupakan batas ambang dimana retak akan menjalar jika $\Delta \mathrm{K}$ mencapai harga lebih besar dari harga $\Delta \mathrm{K}_{\text {th }}$. Pada daerah ini banyak dipengaruhi oleh struktur mikro, lingkungan dan tegangan ratarata .

b). Daerah II

Pada daerah ini mekanisme perambatan retaknya kontinu dan sangat dipengaruhi oleh interaksi antara tegangan rata-rata, lingkungan dan frekuensi beban.

c). Daerah III

Pada daerah ketiga, kerusakan yang terjadi merupakan patah final dengan kecepatan perambatan retak yang tinggi, dimana mekanismenya sama dengan mode statik. Kerusakan ini banyak dipengaruhi oleh struktur mikro, tegangan rata-rata dan tebal benda uji. Patah statik atau patah final ini terjadi jika harga $\Delta \mathrm{K}$ mencapai harga $\Delta \mathrm{K}_{\mathrm{C}}$.

$$
\text { Spearing (1991) memodelkan }
$$

pertumbuhan kerusakan fatigue yaitu hubungan antara $\mathrm{K}_{\mathrm{I}}$ dan $\mathrm{G}_{\mathrm{I}}$ pada notched graphite epoxy laminates untuk material isotropic plane stress dengan deformasi crack yaitu:

$$
\mathrm{K}_{\mathrm{I}}^{2}=\mathrm{G}_{\mathrm{I}} \mathrm{E}
$$

\section{Metode Penelitian}

Penelitian yang dilakukan adalah pengujian fatigue dengan pembebanan reverse bending dengan type specimen double cantilever beam (DCB). Pengujian tersebut digunakan untuk menentukan karakteristik dari material komposit.

Pembuatan spesimen uji dilakukan dengan proses hand lay up dengan menggunakan dua lembar lamina berserat anyam (WR). Diantara kedua lamina disisipi dengan lembaran aluminium dengan ukuran $25 \times 75 \mathrm{~mm}$ sebagai inisiasi retak. Ukuran specimen adalah 25 x 230 $\mathrm{mm}$.

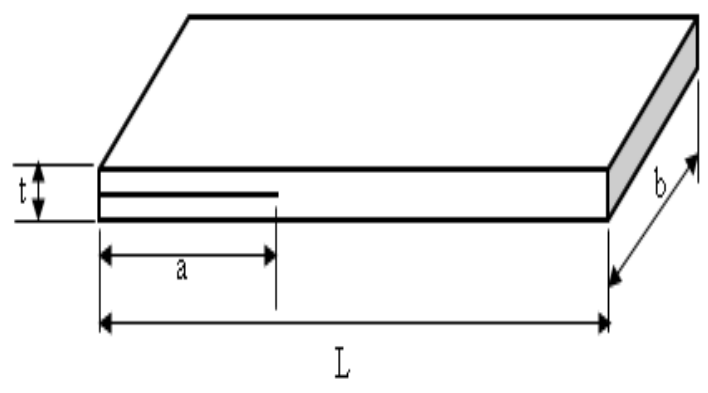

Gambar 3.1 Bentuk spesimen uji fatigue

$$
\begin{array}{rlr}
\text { Ket: } & \\
\mathrm{L} & =230 \mathrm{~mm} \\
\mathrm{~b} & =25 \mathrm{~mm} \\
\mathrm{t} & =2,3 \mathrm{~mm} \\
\mathrm{a} & =75 \mathrm{~mm}
\end{array}
$$

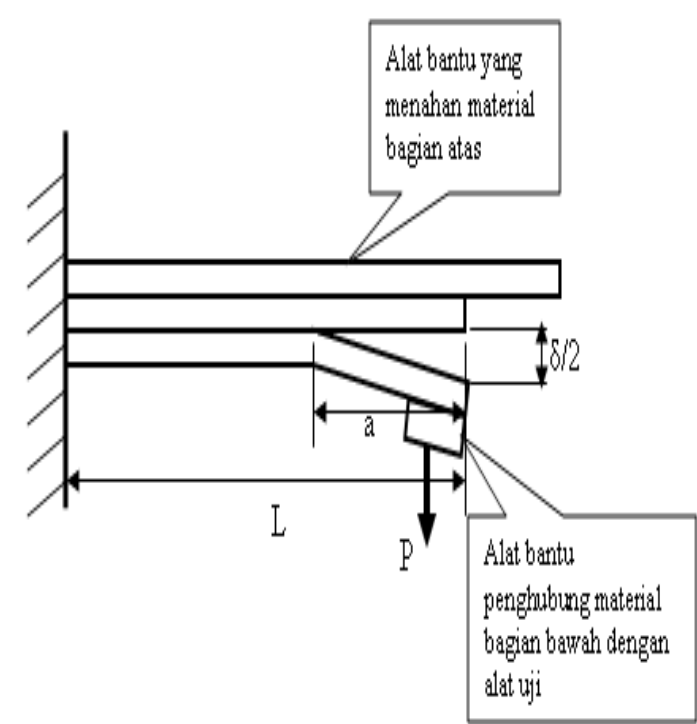

Gambar 3.2 Skema pembebanan pada uji fatigue 
Dari pengujian yang dilakukan, diperoleh data yang selanjutnya dilakukan pengolahan data yang ada.

- Beban

Perhitungan beban menggunakan persamaan dibawah dengan asumsi modulus elastisitas (E) dianggap konstan.

$$
\begin{aligned}
& \frac{\delta}{2}=\frac{P \cdot a^{3}}{3 \cdot E \cdot I} \\
& P=\frac{\delta \cdot 3 \cdot E \cdot I}{2 \cdot a^{3}}
\end{aligned}
$$

- Laju energi yang dibebaskan (strain energy release rate)

Perhitungan laju energi yang dibebaskan menggunakan persamaan pada Gibson (1994), yaitu:

$$
G_{I}=\frac{96 \cdot P^{2} \cdot a^{2}}{E \cdot b^{2} \cdot h^{3}}
$$

- Faktor intensitas tegangan (stress intensity factor)

Perhitungan parameter ini menggunakan rumusan dari Sun dan Sierakowski (1990) yaitu dengan menghubungkan antara factor inensitas tegangan dan laju energi yang dibebaskan dengan asumsi matrik yang terkena pembebanan bersifat isotropic plane stress.

$$
K_{I}^{2}=G_{I} \cdot E
$$

- Laju perambatan retak

Laju perambatan retak menggunakan persamaan secant yaitu:

$$
\frac{d a}{d N}=\frac{\left(a_{i+1}-a_{i}\right)}{\left(N_{i+1}-N_{i}\right)}
$$

\section{Hasil Dan Pembahasan}

Pengujian Tarik

Data yang didapat pada pengujian tarik adalah beban maksimum yang ditunjukkan oleh

\begin{tabular}{|c|c|c|c|c|c|c|c|}
\hline Spesimenl & $\begin{array}{c}A_{0} \\
\left(\mathrm{~mm}^{2}\right)\end{array}$ & $\begin{array}{l}\text { Lo } \\
(\mathrm{mm})\end{array}$ & $\begin{array}{c}\Delta \mathrm{L} \\
(\mathrm{mm})\end{array}$ & $\begin{array}{c}\text { Pmak } \\
\text { (N) }\end{array}$ & $\begin{array}{c}\sigma \mathrm{mak} \\
\left(\mathrm{N} / \mathrm{mm}^{2}\right)\end{array}$ & $f \mathrm{mak}$ & $\begin{array}{c}\mathrm{E} \\
\mathrm{N} / \mathrm{mm}^{2}\end{array}$ \\
\hline I & 57,96 & 178 & 4,26 & 3654 & 63,044 & 0,0239 & 2634,21 \\
\hline II & 60,24 & 177 & 4,21 & 3624 & 60,159 & 0,0238 & 2529,27 \\
\hline III & 57,5 & 178 & 4,39 & 3688 & 64,139 & 0,0247 & 2600,63 \\
\hline IV & 57,5 & 178 & 4,33 & 3708 & 64,487 & 0,0243 & 2650,97 \\
\hline \multicolumn{5}{|l|}{ Ratatara } & 62,957 & 0,0242 & 2603, \\
\hline
\end{tabular}
alat uji dan grafik besarnya beban terhadap pertambahan panjang. Seluruh data pengujian tarik disajikan pada tabel berikut

Tabel 4.1 Hasil pengujian tarik

Dari pengujian tarik yang dilakukan diperoleh hasil berupa modulus elastisitas sebesar 2603,77 N/mm². Bila dibandingkan dengan data pada Gibson (1994) yaitu sebesar $3238,3 \mathrm{~N} / \mathrm{mm}^{2}$ maka hasil yang diperoleh dari pengujian ini lebih kecil. Hal ini kemungkinan disebabkan karena proses pembuatan kurang sempurna sehingga terdapat cacat-cacat yang menurunkan sifat mekanis dari spesimen tersebut.

\section{Pengujian fatigue}

Data berupa panjang retak selama siklus tertentu dari pengujian fatigue dengan menggunakan mesin fatigue reverse bending ditampilkan dalam tabel berikut.

Tabel 4.2 Hasil pengujian fatigue

\begin{tabular}{|r|c|c|c|c|c|}
\hline \multirow{2}{*}{ No } & \multirow{2}{*}{$\begin{array}{c}\text { Jumlah } \\
\text { Siklus }\end{array}$} & \multicolumn{4}{|c|}{ Panjang retak (mm) } \\
\cline { 3 - 6 } & Spesimen I & Spesimen I & Spesimen III & Spesimen IV \\
\hline 1 & 0 & 75,00 & 75,00 & 75,00 & 75,00 \\
\hline 2 & $10^{4}$ & 76,50 & 76,00 & 76,50 & 77,00 \\
\hline 3 & $10^{5}$ & 78,00 & 78,00 & 77,50 & 78,50 \\
\hline 4 & $5.10^{5}$ & 80,00 & 79,50 & 80,00 & 80,00 \\
\hline 5 & $10^{6}$ & 82,50 & 83,00 & 82,00 & 82,50 \\
\hline 6 & $1,5.10^{6}$ & 85,00 & 85,50 & 84,50 & 84,00 \\
\hline 7 & $2.10^{6}$ & 86,00 & 86,00 & 85,50 & 85,50 \\
\hline 8 & $2,5.10^{6}$ & 86,50 & 86,50 & 86,00 & 87,00 \\
\hline 9 & $3.10^{6}$ & 87,00 & 87,00 & 86,50 & 87,50 \\
\hline
\end{tabular}

Dari data yang didapatkan dari pengujian fatigue, selanjutnya dilakukan perhitungan untuk mendapatkan karakteristik dari spesimen akibat pembebanan statik tersebut yang meliputi beban (P), laju energi yang dibebaskan $\left(\mathrm{G}_{\mathrm{I}}\right)$, faktor intensitas tegangan $\left(\mathrm{K}_{\mathrm{I}}\right)$ dan laju perambatan retak (da/dN) dan hasilnya disajikan dalam tabel berikut.

Tabel 4.3 Hasil perhitungan pengujian fatigue spesimen I

\begin{tabular}{|c|c|c|c|c|c|}
\hline $\begin{array}{c}\text { Siklus } \\
\left(10^{5} \text { siklus }\right)\end{array}$ & $\begin{array}{c}\text { a } \\
(\mathrm{mm})\end{array}$ & $\begin{array}{c}\mathrm{P} \\
(\mathrm{N})\end{array}$ & $\begin{array}{c}\mathrm{G}_{\mathrm{I}} \\
(\mathrm{N} / \mathrm{mm})\end{array}$ & $\begin{array}{c}\mathrm{K}_{\mathrm{I}} \\
\left(\mathrm{N} / \mathrm{mm}^{3 / 2}\right)\end{array}$ & $\begin{array}{c}\text { da/dN } \\
\left(10^{-6} \text { mm/siklus }\right)\end{array}$ \\
\hline 0,1 & 76,50 & 2,9486684 & 0,0289115 & 8,67633267 & 150 \\
\hline 1 & 78,00 & 2,7818034 & 0,0267508 & 8,34583627 & 16,67 \\
\hline 5 & 80,00 & 2,5783406 & 0,0241744 & 7,93376060 & 5 \\
\hline 10 & 82,50 & 2,3509771 & 0,0213747 & 7,46021199 & 5 \\
\hline 15 & 85,00 & 2,1495793 & 0,0189688 & 7,02782946 & 5 \\
\hline 20 & 86,00 & 2,0754625 & 0,0181018 & 6,86534178 & 2 \\
\hline 25 & 86,50 & 2,0396795 & 0,0176869 & 6,78620306 & 1 \\
\hline 30 & 87,00 & 2,0047143 & 0,0172838 & 6,70842487 & 1 \\
\hline
\end{tabular}

Tabel 4.4 Hasil perhitungan pengujian fatigue spesimen II 


\begin{tabular}{|c|c|c|c|c|c|}
\hline $\begin{array}{c}\text { Siklus } \\
\left(10^{5} \text { silkilus) }\right.\end{array}$ & (mim) & $\begin{array}{l}P \\
(\mathbb{N})\end{array}$ & $\begin{array}{c}G_{\mathrm{I}} \\
(\mathrm{N} / \mathrm{mm})\end{array}$ & $\begin{array}{c}\mathrm{K}_{\mathrm{l}} \\
\left(\mathrm{N} / \mathrm{mm}^{3 / \mathrm{h}}\right)\end{array}$ & $\begin{array}{c}\text { da/d } \mathbb{N} \\
\left(10^{-6} \mathrm{~mm} / \mathrm{mik} \text { litus }\right)\end{array}$ \\
\hline 0,1 & 76,00 & 3,0072495 & 0,0296798 & 8,79007047 & 100 \\
\hline 1 & 78,00 & 278180034 & 0,0267508 & 8,34583627 & 22,22 \\
\hline 5 & 79,50 & 26272951 & 0,0247803 & 8,0339701015 & 3,75 \\
\hline 10 & 83,00 & 2,3007450 & 0,02086643 & 7,370600064 & 7 \\
\hline 15 & 85,50 & 2,1120875 & 0,0185290 & 6,94587296 & 5 \\
\hline 20 & 86,00 & 20754625 & 0,0181018 & 6,866534178 & 1 \\
\hline 25 & 86,50 & 2,0396795 & 0,01768690 & 6,7062033106 & 1 \\
\hline 30 & 8700 & 200477143 & 0,0172830 & 670842487 & 1 \\
\hline
\end{tabular}

Tabel 4.5 Hasil perhitungan pengujian fatigue spesimen III

\begin{tabular}{|c|c|c|c|c|c|}
\hline $\begin{array}{c}\text { Sikjus } \\
\left(10^{5} \text { sikilus }\right)\end{array}$ & $\begin{array}{c}a \\
(\mathrm{~mm})\end{array}$ & $\begin{array}{l}P \\
(\mathbb{N})\end{array}$ & $\begin{array}{c}\mathrm{G}_{\mathrm{I}} \\
(\mathrm{N} / \mathrm{mm})\end{array}$ & $\begin{array}{c}\mathrm{K}_{\mathrm{I}} \\
\left(\mathrm{N} / \mathrm{mmm}^{3 / 2}\right)\end{array}$ & $\begin{array}{c}\mathrm{da} / \mathrm{dN} \\
\left(10^{-6} \mathrm{~mm} / \mathrm{sikl} \mathrm{lus}\right)\end{array}$ \\
\hline 0,1 & 76,50 & 2,4486664 & 0,0289115 & 867633267 & 150 \\
\hline 1 & 77,50 & 2,8359929 & 0,0274479 & 8,453071866 & 11,11 \\
\hline 5 & 80,00 & 2,5783406 & 0,0241744 & 7,933760600 & 6,25 \\
\hline 10 & 82,00 & 2,3942455 & 0,0219008 & 7,55146755 & 4 \\
\hline 15 & 84,50 & 2,1879637 & 0,0194218 & 7,11124510 & 5 \\
\hline 20 & 85,50 & 2,1120875 & 0,0185290 & 694507296 & 2 \\
\hline 25 & 86,00 & 2,0754625 & 0,0181018 & 6,86534178 & 1 \\
\hline 30 & 86,50 & 2,0396795 & 0,01766699 & 6,786203006 & 1 \\
\hline
\end{tabular}

Tabel 4.6 Hasil perhitungan pengujian fatigue spesimen IV

\begin{tabular}{|c|c|c|c|c|c|}
\hline $\begin{array}{c}\text { Sikiklus } \\
\left(10^{5} \text { silklus }\right)\end{array}$ & $\stackrel{a}{(m m)}$ & $\begin{array}{l}P \\
(\mathbb{N})\end{array}$ & $\begin{array}{c}G_{I} \\
(\mathrm{~N} / \mathrm{mm})\end{array}$ & $\begin{array}{c}\mathrm{K}_{\mathrm{I}} \\
\left(\mathrm{N} / \mathrm{mm}^{3 / 2}\right)\end{array}$ & $\begin{array}{c}\mathrm{da} / \mathrm{dN} \\
\left(10^{-6} \mathrm{~mm} / \mathrm{silk} \mathrm{kls}\right)\end{array}$ \\
\hline 0,1 & 77,00 & 2,891599 & 0,0281678 & 8,564018066 & 200 \\
\hline 1 & 78,50 & 27289958 & 0,0260758 & 8,23985847 & 16,67 \\
\hline 5 & 80,00 & 2,57834006 & 0,0241744 & 7,93376060 & 3,75 \\
\hline 10 & 82,50 & 2,3509771 & 0,0213747 & 7,66021199 & 5 \\
\hline 15 & 84,00 & 2,27272675 & 0,01980803 & 7,19615474 & 3 \\
\hline 20 & 85,50 & 2,1120875 & 0,0185290 & 6,94587296 & 3 \\
\hline 25 & 87,00 & 2,0047143 & 0,0172838 & 6,70842487 & 3 \\
\hline 30 & 87,50 & 1,9705438 & 0,0168921 & 663197621 & 1 \\
\hline
\end{tabular}

Hubungan antara jumlah siklus, panjang retak, faktor intensitas tegangan dan laju energi yang dibebaskan.

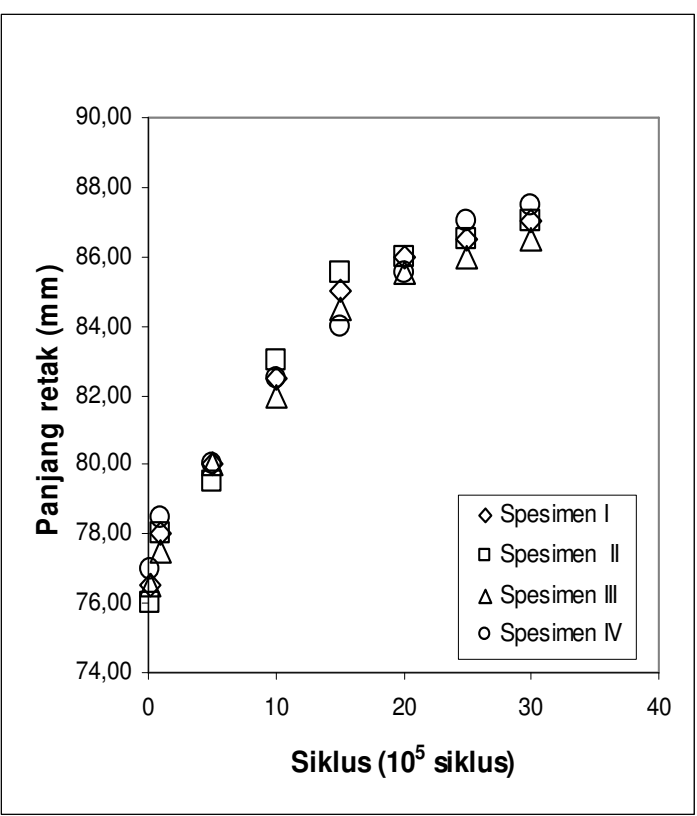

Gambar 4.1 Panjang retak (a) Vs Jumlah siklus (siklus)

Dari grafik pada gambar 4.1 terlihat bahwa terjadi pertambahan panjang retak pada penambahan jumlah siklus. Panjang retak bertambah dengan laju yang tinggi pada awal pembebanan dan mengalami penurunan dan dengan laju yang landai pada siklus ke 2 jutaan. Pembebanan dihentikan pada siklus ke 3 jutaan.

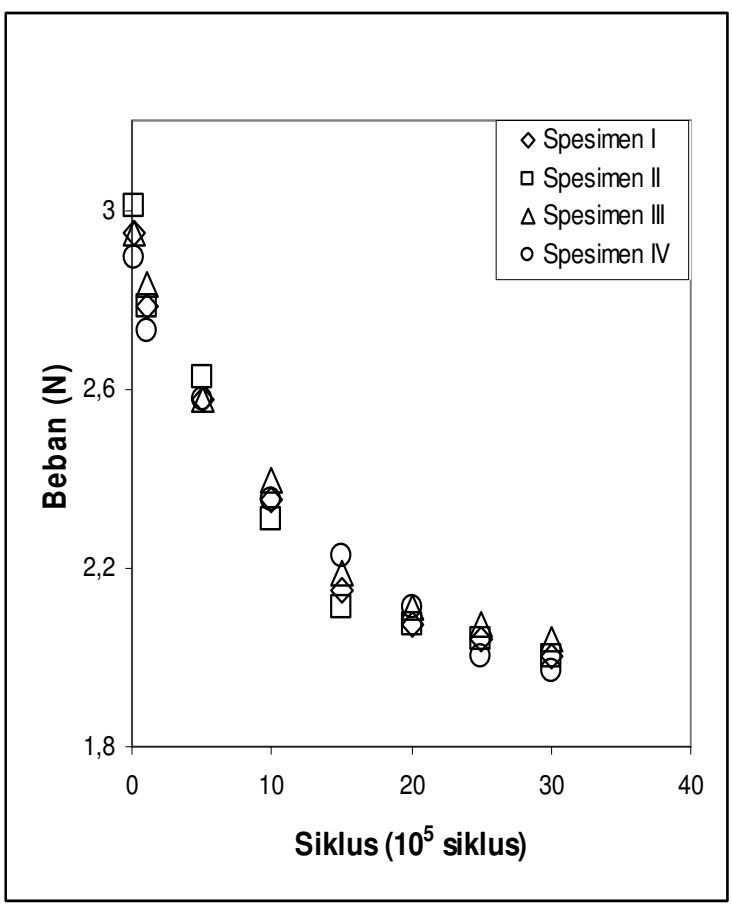

Gambar 4.2 Beban perambaan retak (N) Vs Jumlah siklus (siklus)

Pada gambar 4.2 dapat diamati terjadi penurunan beban yang dibutuhkan untuk 
perambatan retak pada penambahan jumlah siklus. Penomena yang sama diamati pada kebutuhan beban yaitu penurunan drastis pada awal pembebanan yang diikuti penurunan yang landai setelah siklus ke 2 jutaan.

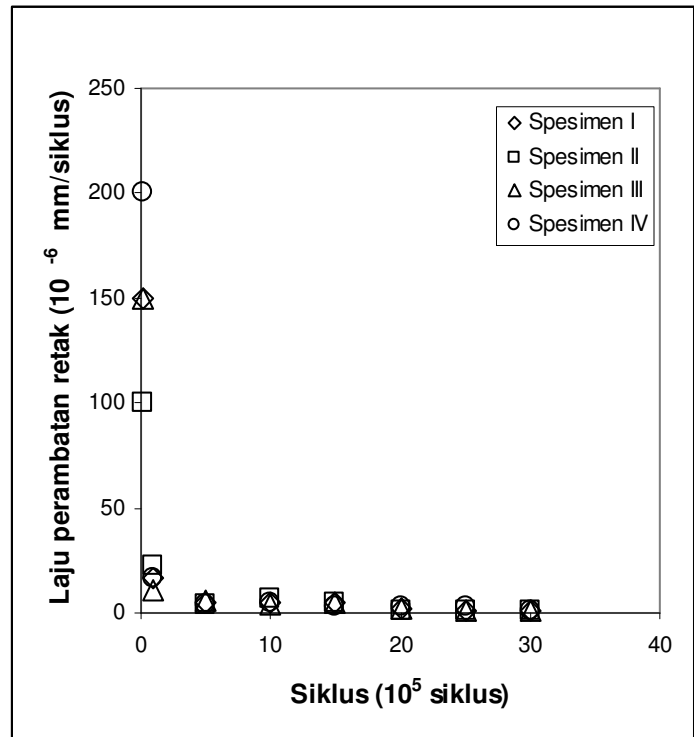

Gambar 4.3 Laju perambatan retak (da/dN) Vs Jumlah siklus (siklus)

Dari gambar diatas terlihat bahwa dengan bertambahnya siklus maka laju perambatan retak akan semakin rendah, dimana terlihat derajat penurunan yang sangat curam diawal pembebanan dan laju yang hamper konstan pada siklus diatas 500 ribuan.

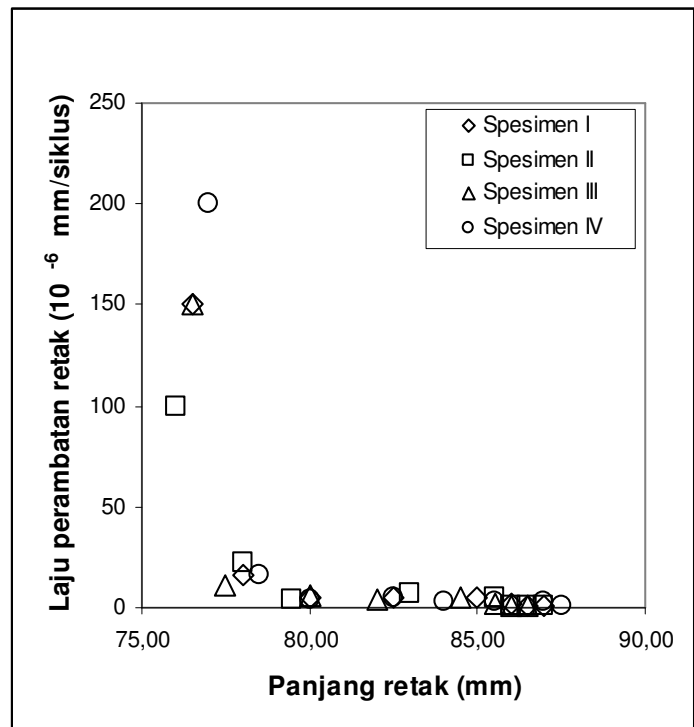

Gambar 4.4 Laju perambatan retak (da/dN) Vs Panjang retak (a)

Pertambahan panjang retak menyebabkan penurunan laju perambatan retak. Dari gambar 4.4 terlihat bahwa setelah panjang retak mencapai $80 \mathrm{~mm}$ laju perambatan retak cenderung konstan.

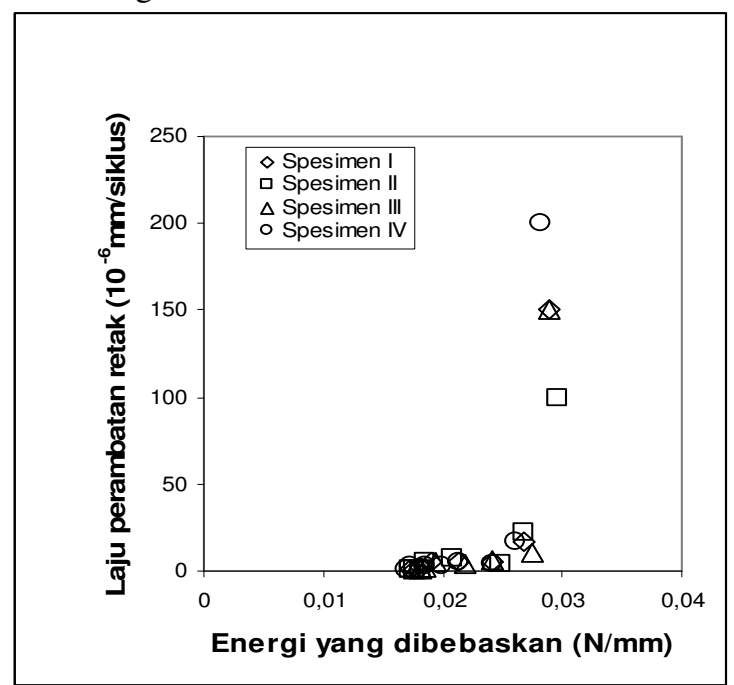

Gambar 4.5 Laju perambatan retak (da/dN) Vs Energi yang dibebaskan $(\mathrm{G})$

Laju pembebasan energi (G) dan Faktor intensitas tegangan $(\mathrm{K})$ memiliki pengaruh yang hampir sama terhadap laju perambatan retak $(\mathrm{da} / \mathrm{dN})$. Laju perambatan retak semakin meningkat dengan meningkatnya energi yang dibebaskan, demikian juga dengan faktor intensitas tegangan. Pola yang ditunjukkan hampir sama yaitu peningkatan yang perlahan pada permulaan dan terjadi laju yang sangat tinggi pada harga $\mathrm{G}$ dan $\mathrm{K}$ tertentu ( $\mathrm{Gb} 4.5$ dan 4.6)

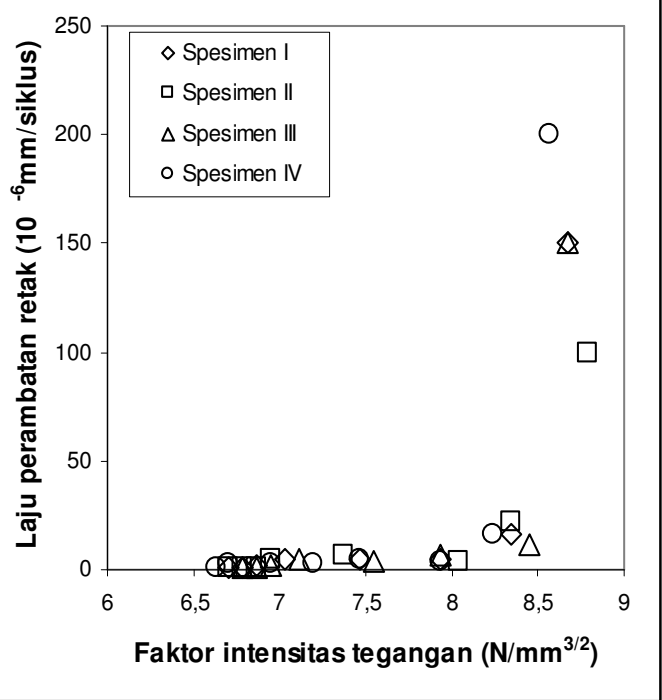

Gambar 4.6 Laju perambatan retak (da/dN) Vs Faktor intensitas tegangan (K)

Pembahasan 
Pada pengujian fatigue berdasarkan pada tipe pembebanan dengan regangan terkontrol dimana pembebanan diberikan pada setengah spesimen bagian bawah, terlihat bahwa dengan bertambahnya waktu pengujian (bertambahnya jumlah siklus) retak yang dihasilkan semakin panjang. Pada awal pengujian sampai siklus $2.10^{6}$ pertambahan retak lebih besar bila dibandingkan dengan pertambahan retak setelah tercapainya siklus tersebut.

Dari gambar 4.1 dan 4.2 tampak bahwa kecenderungan penurunan pertambahan panjang sebanding dengan penurunan beban yang dterima oleh spesimen. Pada awal proses pertambahan panjang sangat besar yang disebabkan oleh karena beban yang diterima oleh material besar. Apabila pengujian diteruskan maka pada siklus tertentu akan tercapai kondisi dimana beban yang diterima oleh spesimen sangat kecil dan perubahan panjang retak juga semakin kecil sehingga akhirnya tidak ada pertambahan panjang retak.

Dari grafik hubungan antara perambatan retak dengan penambahan siklus dapat dilihat laju perambatan retak sangat tinggi diawal siklus dan dengan bertambahnya siklus laju perambatannya semakin menurun. Jika dihubungkan dengan gambar 4.2 tampak bahwa pada awal proses pengujian, beban yang diterima oleh spesimen sangat besar sehingga berpengaruh terhadap laju perambatan retak. Hal ini terjadi pada awal pembebanan sampai pada siklus $5.10^{5}$ dan setelah itu perubahan laju perambatan retak sangat kecil.

Jika pengujian dilanjutkan maka akan didapatkan kondisi dimana laju perambatan retaksangat kecil sampai tidak ada perambatan retak sama sekali. Laju perambatan retak ini dapat dihubungkan dengan bertambahnya panjang retak seperti pada gambar 4.4, dimana dengan bertambahnya panjang retak, laju perambatan retak akan turun. Ini terjadi karena dengan bertambahnya panjang retak pada kondisi defleksi konstan, maka akan terjadi penurunan beban yang diterima oleh spesimen. Dengan penurunan beban maka energi yang dibebaskan untuk menjalankan retak juga akan turun. Penurunan energi ini menyebabkan faktor intensitas tegangan yang terjadi juga akan turun, sehingga laju perambatan retak akan turun karena faktor intensitas tegangan sangat menentukan distribusi tegangan pada ujung retakan.

Dari gambar 4.5 dan 4.6 terlihat bahwa laju perambatan retak dipengaruhi oleh kedua faktor tersebut, dimana tampak pada harga $\mathrm{K}_{\mathrm{I}}$ dan $\mathrm{G}_{\text {I }}$ mencapai $7,2 \mathrm{~N} / \mathrm{mm}^{3 / 2}$ dan $0,022 \mathrm{~N} / \mathrm{mm}$ terjadi fenomena diaman perubahan $\mathrm{K}_{\mathrm{I}}$ dan $\mathrm{G}_{\mathrm{I}}$ yang sangat kecil saja akan mendapat respon berupa laju perambatan retak yang sangat besar. Pada pengujian selanjutnya dengan penambahan $\mathrm{K}_{\mathrm{I}}$ dan $\mathrm{G}_{\mathrm{I}}$ akan mencapai harga kritis yang merupakan batas terjadinya kerusakan yaitu patah statis.

\section{Simpulan}

Berdasarkan hasil pengujian dan analisis data, maka dapat diambil kesimpulan sebagai berikut:

1. Laju perambatan retak dengan menggunakan metode secant mengalami penurunan pada jumlah siklus yang meningkat

2. Bertambahnya siklus mengakibatkan faktor intensitas tegangan $\left(\mathrm{K}_{\mathrm{I}}\right)$ dan energi yang dibebaskan $\left(\mathrm{G}_{\mathrm{I}}\right)$ mengalami penurunan

3. Berkurangnya energi yang dibebaskan dan faktor intensitas tegangan berpengaruh pada distribusi tegangan pada ujung retakan mengakibatkan laju pertambahan retak menurun.

\section{Daftar Pustaka}

1. Carpinteri, Andrea. 1992, "Reinforced Concrete Beam Behavior Under Cyclic Loading" Application of Fracture Mechanic to Reinforced Concrete. Elsevier Science Publisher LTD.

2. Han, Kyung S. 1984,'”The Interlaminar Frakture Energy of Glass Fiber Reinforced Polymer Composite". Glass Reinforced Polymer System, Laucaster Pennsylvania : Technomis Publishing Co. Inc

3. Paris D.C and Erdogen F. 1963,"Critical Analysis of Crack Propagation Laws", Transactions of ASME, Journal of Basics Engineering, $85,528-534$

4. Sun, C.T and Sierakowski, R.L. 1980,"Frakture Characterization of Composite of Chopped Fiber Glass Reinforcement", SAMPE Quarterly, 11 (4), 2-15

5. Whitney, J.M and Hoogsteden, W. 1992,"Double Cantilever Beam Test for Characteristizing Mode I Delamination of Composite Material", Journal of Reinforced Plastics and Composite, vol 1, 297-313 
6. Harrison N.L, 1972,"Strain Energy Release Rate for Turning Crack", Fiber Sci. Teknol. 5, 197-212

7. Sih G.C, 1973,"A Special Theory of Crack Propagation", in Metode of Analysis and Solution of Crack Problem, Mechanic of Fracture I pp.XXI-XLV, Noordhoff Int. publ. The Nederland.

8. O'Brien, T.K, 1982,"Characterization of Delamination Onset and Growth in a Composite Laminate", in K.L Refsnider (ed), Damage in Composite Material, ASTM STP. 775, 140-167, American Society for Testing Material, Philadelphia, PA 